\title{
セルフベアリングモータのセルフセンシング化の研究*
}

\author{
松田健 - *1, 黒須利 幸*2, 岡田養二*1
}

\section{Self-Sensing Control Technique of Self-Bearing Motor}

\author{
Ken-ichi MATSUDA*3, Toshiyuki KUROSU and Yohji OKADA \\ ${ }^{* 3}$ Department of Mechanical Engineering, Ibaraki University, \\ 4-12-1 Nakanarusawa-cho, Hitachi-shi, Ibaraki, 316-8511 Japan
}

\begin{abstract}
This paper introduces a self-sensing technique of self-bearing motor by using the differential transformer principle. This self-sensing technique has wide linear range than the other technique due to the use of the carrier frequency component. Therefore it is expected to have robust displacement information for the temperature fluctuation. This technique uses the structure of the motor and levitation coils which are similar to the differential transformer. In this paper, the fundamental principle is introduced how the self-sensing is achieved by the differential transformer principle. Then the differential output characteristics is examined experimentally. Finally levitated rotating test is carried out by self-sensing control.
\end{abstract}

Key Words: Rotary Machinery, Magnetic Bearing, Digital Control, AC Motor, Self-Sensing. Technique

\section{は じめに}

近年, モータを非接触で支持でき, 高速回転可能で メンテナンスフリーなセルフベアリングモータが開発 され，研究が進められている ${ }^{(1)}$. 通常のセルフベア リングモータは, フィードバックによる位置制御を行 うために変位センサを必要とする. 従って, 変位セン サのコストや設㯰スペースが問題となる．これらの問 題を解決するため, アクチュエータを変位センサとし て併用するセルフセンシング技術が提案されている. これまでに提案されたセルフセンシングの方式として は，大きく分けてオブザーバ方式 (2) と搬送波方式 (3) の二つの方式がある. オブザーバ方式は, 制御電圧と 電流の関係からプラントのオブザーバを構成し, 変位 を推定する方式で, 特別なハードウェアを必要としな い利点はあるが, 精度の高いオブザーバを構成する必 要がある. 一方搬送波方式は, 制御電流の搬送波成分 から変位を推定するため, フィルタ回路や復調回路な どのハードウェアを必要とするが, 直接変位信号が得 られるという利点がある. しかし搬送波を用いる方式 の場合でも, 単に電磁石のインダクタンスの変化から 変位を推定すると, 得られる信号の線形範囲は広いと

* 原稿受付 2003 年 4 月 21 日.

*1 正員, 茨城大学工学部( 316-8511 日立市中成沢町 4-121).

*2 茨城大学大学院理工学研究科.

E-mail : matsu@mech.ibaraki.ac.jp
は言えず，発熱などによりその特性が変化する.これ らの問題を解決するために, 差動トランス方式による セルフセンシング技術が提案されている ${ }^{(4)}$. 差動卜 ランス方式は，アクチュエータの巻線構造に差動トラ ンスと同じ特性を持たせることにより，通常の搬送波 を用いたセルフセンシング技術に比べ, 線形範囲がよ り広く，熱変動などの影㗽を受けにくい出力を得るこ とができる. 本研究では, 差動トランス方式により, セルフベアリングモータのセルフセンシング化をはか り，より実用性の高いモータを開発することを目的と する.

\section{1. 浮上回転理敦}

本研究では，モータ効率が良くロータでの発熱が少 ない PM 同期型モータを用い， \pm 2 極理論を用いたセ ルフベアリングモータの浮上理論 (1) を適用する. 従つ て，本モータはステータ極数＝ロータ極数 \pm 2 のとき, 回転角に関係なく一定した浮上力を得ることができる. このとき, $x, y$ 方向の浮上力はそれぞれ式 (1), (2) の ようになる.

$$
\begin{aligned}
F_{x} & =\frac{\pi B_{R} r w}{2 \mu_{0}} B_{F x} \\
F_{y} & =\frac{\pi B_{R} r w}{2 \mu_{0}} B_{F y}
\end{aligned}
$$

ここで, $B_{R}$ は界磁磁束の波高值， $r, w$ はそれぞれ半径 と厚み, $\mu_{0}$ は真空の透磁率， $B_{F_{x}}, B_{F_{y}}$ はそれぞれ $x, y$ 方向の制御磁束の波高值である. 従って, $x, y$ 方向の 

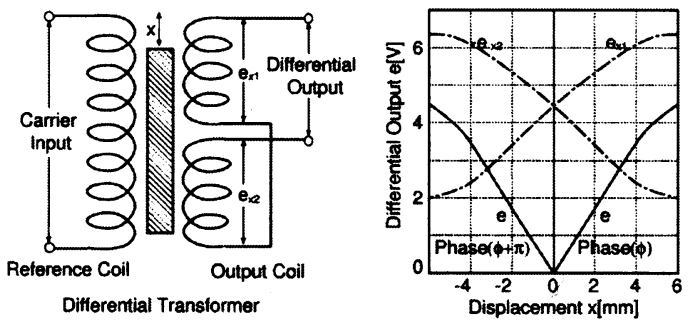

Fig. 1 Principle of Differential Transformer

制御磁束を変化させることによって，ロータの位置を $x y$ 平面上で制御することができる.

また, 回転トルクは, BIL 則 (フレミングの左手の 法則)から式 (3)のように計算することができる.

$$
T=B_{R} I_{M} r L \pi \cos \psi
$$

ここで $I_{M}$ は回転電流の波高値, $\psi$ は回転電流の位相 差, $L$ は巻線の有効長さ (通常 $L=w$ ) である. 従って, 位相差 $\psi$ を変化させることによって, 回転トルクを制 御することができる.

\section{2. セルフセンシングの原理・理論}

図 1 に差動トランスの原理図を示す. 差動トランス は 1 次側コイル，2次側コイル及び鉄心から構成され， 1 次側コイルに一定周波数の電圧を加え励磁すること で, 2 次側コイルには鉄心の動きに応じた差動電圧が 誘起される. この出力を位相検波することで変位に比 例した出力が得られる.

本モータの巻線構成を図 2 に示す. 本モータは, 浮 上制御と回転用の 2 系統の巻線を必要とする. その中 で, 回転用巻線は対向する相が同相に, 浮上用巻線は 対向する相が逆相に結線されている. 従って, 回転用 巻線を差動トランスの 1 次側とみなすと, 浮上用巻線 を差動トランスの 2 次側とみなすことができ, 差動卜 ランスの原理によりロータの変位推定を行うことが可 能となる.

本研究では, 回転用巻線のU 相を $10[\mathrm{kHz}]$ の搬送波 周波数でパルス幅変調駆動し, U 相に直交する浮上用 巻線の $\boldsymbol{\alpha}^{\prime}, \boldsymbol{\beta}^{\prime}$ 相に誘導される電圧によって図 3 の浮上 用アンプの検出抵抗を流れる電流を検出し, セルフセ ンシングを行う。これは，浮上制御指令による電圧変 動が大きく，変位情報を含む誘導電圧を検出すること が困難だったためである、また， $\boldsymbol{\alpha}^{\prime}, \boldsymbol{\beta}^{\prime}$ と同じ位㯰に 制御巻線とは別系統の検出巻線 $D_{x}, D_{y}$ を巻き, 同様に $\mathrm{U}$ 相を PWM 駆動したときに, $D_{x}, D_{y}$ に誘導される電 圧を検出し，この二つの方式のセルフセンシング特性 を比較する. 検出巻線を用いた場合, 変位推定の感度

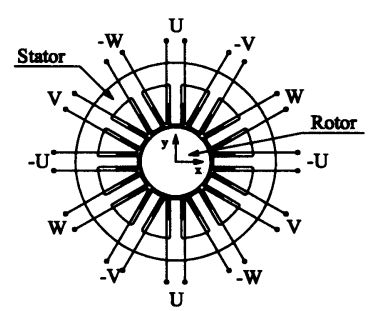

3 Phase 4 Pole Motoring Coils

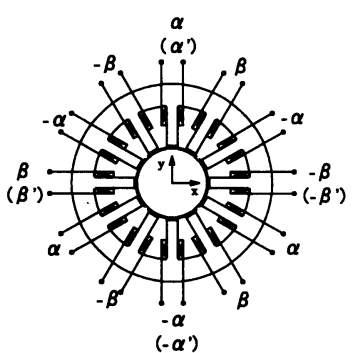

2 Phase 6 Pole Levitation Coils

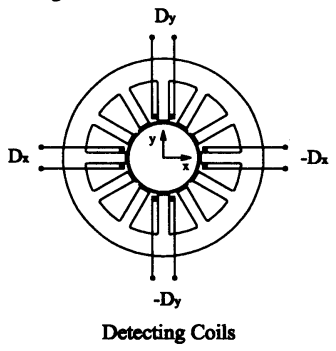

Fig. 2 Arrangement of Coils

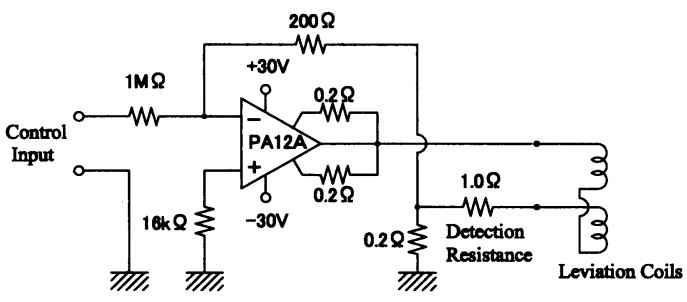

Fig. 3 Levitation Amplifier

は高くなるので, 検出巻線の巻数は少なく $(3 \sim 10$ 巻 $)$ てよく, 設置スペースの増加はほとんどない，本実験 装置において, 浮上用巻線, 回転用巻線の巻数はそれ ぞれ 91 巻, 検出巻線の巻数は 9 巻とした.

次に相互インダクタンスの理論解析を行い，本モー タが差動トランス方式により, セルフセンシング可能 であるということを示す。まず, $F_{U}(\theta)$ はU 相の単位 電流による起磁力分布で，正弦波状に分布すると仮定 すると，以下のようにおける.

$$
F_{U}(\theta)=F_{0} \cos 2 \theta
$$

また，ロータが図 4 に示すように， $x, y$ に変位したと きのエアギャップ $l(\theta)$ を

$$
l(\theta) \simeq l_{0}+x \sin \theta-y \cos \theta
$$

とすると, $\theta$ におけるロータとステータ間の微小部分 のパーミアンス $d P_{e q}$ は, 半径 $r$, 厚さ $w$ のロータであ 


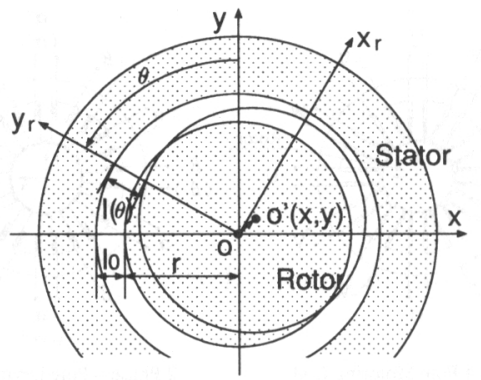

Fig. 4 Relation between Rotor Motion and Airgap れば磁気的等価回路より以下のように近似できる.

$$
d P_{e q}=\frac{\mu_{0} r w\left(l_{0}-x \sin \theta+y \cos \theta\right)}{l_{0}^{2}} d \theta
$$

さらに, $\alpha, \beta$ 相巻線の単位電流による起磁力 $F_{\alpha}(\theta)$, $F_{\beta}(\theta)$ が正弦波状に分布する場合，

$$
\begin{aligned}
& F_{\alpha}(\theta)=F_{1} \cos 3 \theta \\
& F_{\beta}(\theta)=F_{1} \sin 3 \theta
\end{aligned}
$$

と表わせるから， $\alpha, \beta$ 相巻線に鎖交する微小磁束は,

$$
\begin{aligned}
& d \psi_{U \alpha}=F_{U}(\theta) F_{\alpha}(\theta) d P_{e q} \\
& d \psi_{U \beta}=F_{U}(\theta) F_{\beta}(\theta) d P_{e q}
\end{aligned}
$$

となる.これは, $\mathrm{U}$ 相巻線と $\alpha, \beta$ 相巻線間の単位電 流当たりの微小鎖交磁束であり, 相互インダクタンス $M_{U \alpha}, M_{U \beta}$ は,

$$
\begin{aligned}
M_{U \alpha} & =\int_{0}^{2 \pi} F_{U}(\theta) F_{\alpha}(\theta) d P_{e q}=\frac{F_{0} F_{1} \mu_{0} r w \pi}{2 l_{0}^{2}} y \\
M_{U \beta} & =\int_{0}^{2 \pi} F_{U}(\theta) F_{\beta}(\theta) d P_{e q}=-\frac{F_{0} F_{1} \mu_{0} r w \pi}{2 l_{0}^{2}} x
\end{aligned}
$$

で与えられる.この結果, $M_{U \alpha}$ は $y$ 方向, $M_{U \beta}$ は $x$ 方 向のみに依存する特性を持ち, $\alpha, \beta$ 相巻線の誘導電圧 からそれぞれ $y, x$ の変位の推定が可能である.

また, $x, y$ 方向の直接的な差動出力である $U$ 相上に ある $\alpha, \beta$ 相巻線 $\left(\alpha^{\prime}, \beta^{\prime}\right)$ のみを用いる場合は，この巻 線の単位電流による起磁力 $F_{\alpha^{\prime}}(\theta), F_{\beta^{\prime}}(\theta)$ をDirac の デルタ関数を用いて,

$$
\begin{aligned}
& F_{\alpha^{\prime}}(\theta)=F_{1}[\delta(\theta)+\delta(\theta-\pi)] \\
& F_{\beta^{\prime}}(\theta)=F_{1}\left[\delta\left(\theta-\frac{\pi}{2}\right)+\delta\left(\theta+\frac{\pi}{2}\right)\right]
\end{aligned}
$$

とすると, 相互インダクタンス $M_{U \alpha^{\prime}}, M_{U \beta^{\prime}}$ は, 突極 部分の面積を $S$ として,

$$
M_{U \alpha^{\prime}}=\frac{2 F_{0} F_{1} \mu_{0} S}{l_{0}^{2}} y
$$

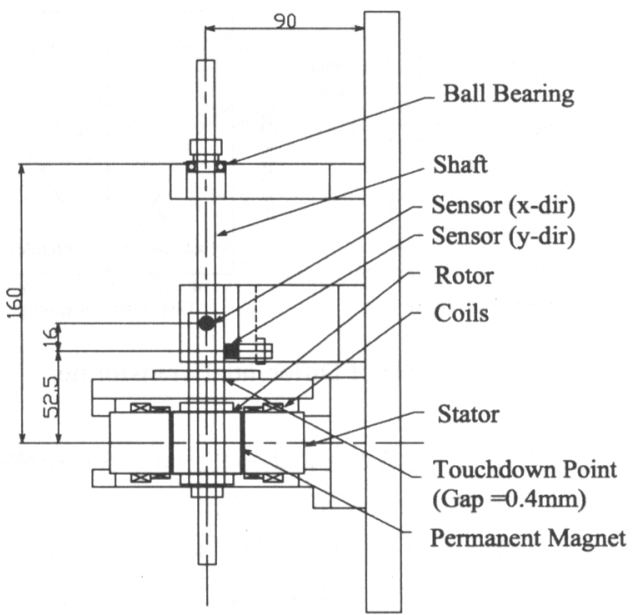

Fig. 5 Schematic of Experimental Setup

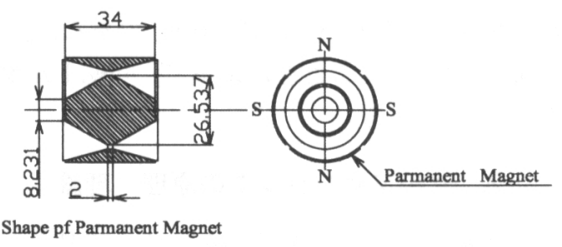

Fig. 6 Schematic of Rotor

$$
M_{U \beta^{\prime}}=\frac{2 F_{0} F_{1} \mu_{0} S}{l_{0}^{2}} x
$$

となり, $\alpha^{\prime}, \beta^{\prime}$ 相巻線の誘導電圧から $y, x$ の変位推定 が可能である. 従って, 検出巻線を用いた場合も同様 に, $D_{x}, D_{y}$ 巻線の誘導電圧から $x, y$ の変位推定が可能 となる。

\section{3. 実験装置の構成}

図 5 に実験装置の概略図を, 図 6 にロータの構造を 示す．本モータはインナーロータ型で，ロータ軸の上 部を玉軸受で単純支持し、ラジアル $x, y$ 方向にのみ 自由度を持つ、ロータは、直径 $38.6 \mathrm{~mm}$, 厚さ $0.35 \mathrm{~mm}$ の珪素鋼鈑 (材質 : 35A300) を103 枚積層したもので, その表面には厚さ $0.7[\mathrm{~mm}]$ のネオジウム系永久磁石 (NEOMAX-38H, リコイル比透磁率 1.05) が N, S 交互 に 4 枚張付けられている. ロータとステータ間のエア ギャップは約 $1.0[\mathrm{~mm}]$ で, 直接接触するのを防ぐため に約 $0.4[\mathrm{~mm}]$ のタッチダウンを設け,ラジアル 2 方向 の変位は渦電流式変位センサにより検出している.

制御系の構成を図 7 に示す. 回転用巻線の U 相を PWM インバータを用いて PWM 駆動し; 浮上制御巻 


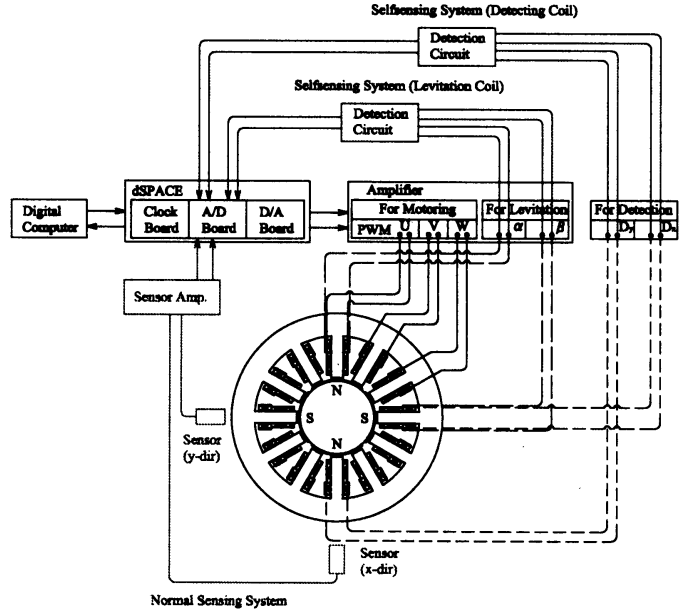

Fig. 7 Control System

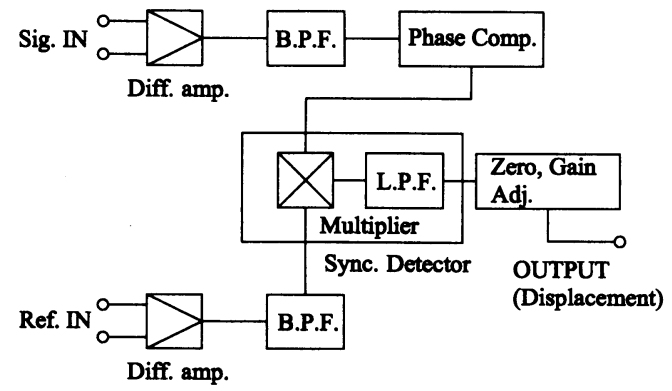

Fig. 8 Configuration of Detection Circuit

線の $\alpha^{\prime}, \beta^{\prime}$ もしくは検出巻線の $D_{x}, D_{y}$ に誘導された 差動信号を検出することによって変位推定を行う．本 モータの制御には DSP(dSPACE DS1104)を利用した ディジタル制御を用いる. 浮上制御は, 変位センサも しくはセルフセンシング出力を $\mathrm{A} / \mathrm{D}$ コンバータを通 してDSPボードに取り込み，ロータ変位に応じて計 算した制御電流を D/A コンバータからパワーアンプ を介して各巻線に出力することによって行う。浮上制 御にはPID コントローラを用いた。.また，回転制御は ロータの界磁磁束に同期した回転磁界を作り出す同期 モータ制御を行った.

セルフセンシングに用いる検出回路の構成を図 8 に 示す．まず，検出用巻線に誘導された差動信号の搬送 波成分をバンドパスフィルタを用いて抽出する. また, $\mathrm{U}$ 相を PWM 駆動している基準信号の搬送波成分を同 様に抽出する.この基準信号と差動信号の位相関係を 位相補侻回路により調整し, 掛算器を用いて変位の符 号に応じて差動出力波形を全波整流する.この出力を カットオフ周波数 $1.5[\mathrm{kHz}]$ のローパスフィルタに送
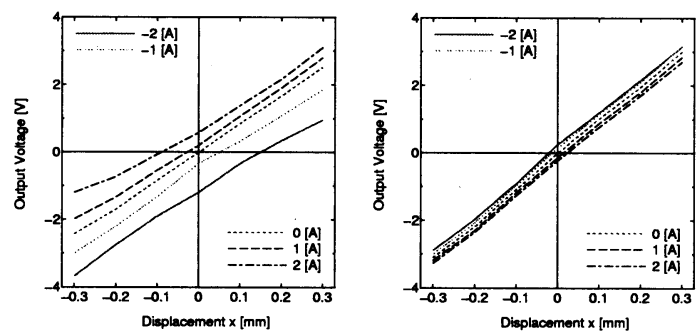

Fig. 9 Characteristics of Estimated Displacement using Levitation Coils ( $x$-axis, $\omega t=0$ (Left), $\omega t=\frac{\pi}{4}$ (Right))
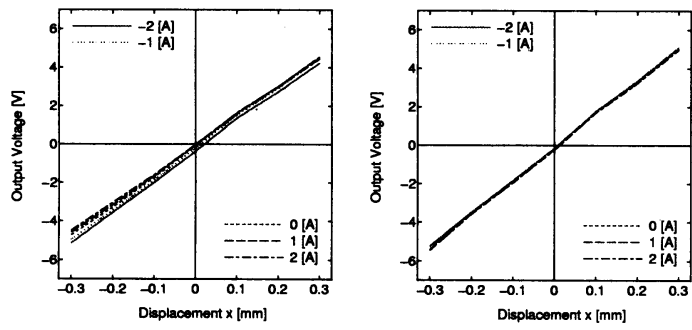

Fig. 10 Characterisitics of Estimated Displacement using Detecting Coils ( $x$-axis, $\omega t=0$ (Left), $\omega t=\frac{\pi}{4}($ Right))

り，搬送波成分を除去することによって，ロータの推 定変位を得る。

\section{4. 実 臨 結 果}

$4 \cdot 1$ 変位推定实験 はじめに浮上制御巻線を検 出巻線として, 変位推定実験を行った. 実験は, ロー 夕を $-0.3[\mathrm{~mm}]$ から $+0.3[\mathrm{~mm}]$ まで変位させることに よって行い, 制御電流による影響を調べるために検出 方向の浮上制御巻線に $-2[\mathrm{~A}]$ から $+2[\mathrm{~A}]$ までの直流 電流を入力した. また, ロータが回転したときの影響 を調べるため, 永久磁石の $\mathrm{N}$ 極と検出スロットが対向 する位置をロータの角位置 $\omega t=0$, 永久磁石の $\mathrm{N}$ 極 と $\mathrm{S}$ 極の間に検出スロットがある場合を $\omega t=\frac{\pi}{4}$ とし, それぞれの位置で実験を行った. 測定結果を図 9 に示 す. 測定結果から, 変位に対して線形な出力が得られ ていることが確認されるが, 変位推定は入力電流及び 永久磁石の位㯰によって変動してしまった.このため, 電流変動の少ない安定した状態では, セルフセンシン グによる浮上制御に成功したが，制御電流により差動 出力に変動が生じ，セルフセンシング制御によりロー 夕を浮上回転させることはできなかった，これは，誘 導電圧によって検出抵抗を流れる微小な電流を検出し ていたので, 永久磁石, 制御アンプ等の影響を含め, 


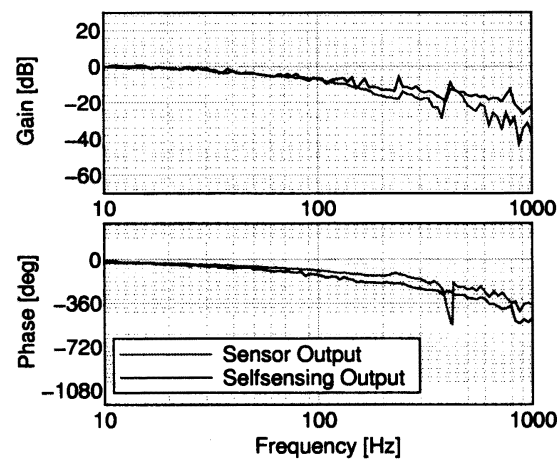

Fig. 11 Frequency Response by Sensor Control ( $x$-axis, $\omega t=0$ )

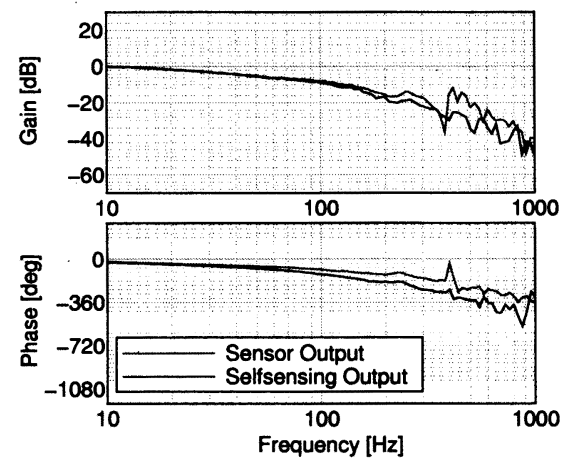

Fig. 12 Frequecy Response by Sensor Control ( $x$-axis, $\left.\omega t=\frac{\pi}{4}\right)$

磁気回路における誘導特性変動の影響を大きく受けて しまったためではないかと考えられる.

そこで，浮上制御巻線とは独立した検出巻線を用い て, 誘導電圧を利用した変位推定実験を行った. 測定 結果を図 10 に示す. 測定結果から，制御電流による 差動出力の変動を抑えることができ, 変位に対して線 形な出力を得られているということが確認された。こ れは, 制御巻線とは独立した検出巻線を用いて誘導電 圧を利用したセルフセンシングを行うことで SN 比が 改善され, 磁気回路の変動による影響を受けにくい出 力を得ることができたためであると考えられる.これ より以降では, 独立した検出巻線を用いて, セルフセ ンシングによる浮上実験を行う.

4.2 浮上实険 次に, 本モ一タの浮上特性を調べ るために，周波数応答を測定した．測定方法は，変位 センサ制御もしくはセルフセンシング制御によりロー タを安定浮上した状態で, 制御システムにロータが $\pm 0.01[\mathrm{~mm}]$ 振動するような正弦波外乱を入力し，ロー 夕変位を出力とすることで求められる伝達関数を FFT

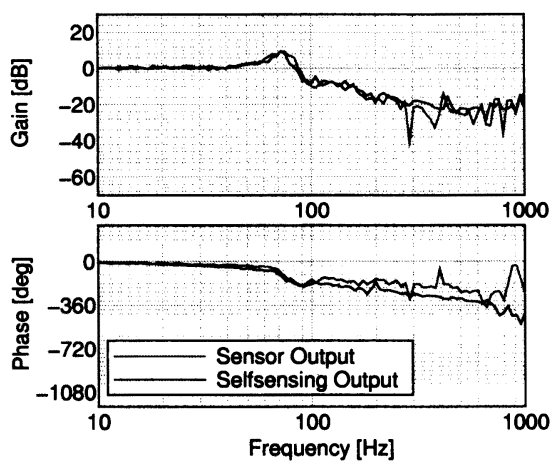

Fig. 13 . Frequency Response by Selfsensing Control ( $x$ axis, $\omega t=0$ )

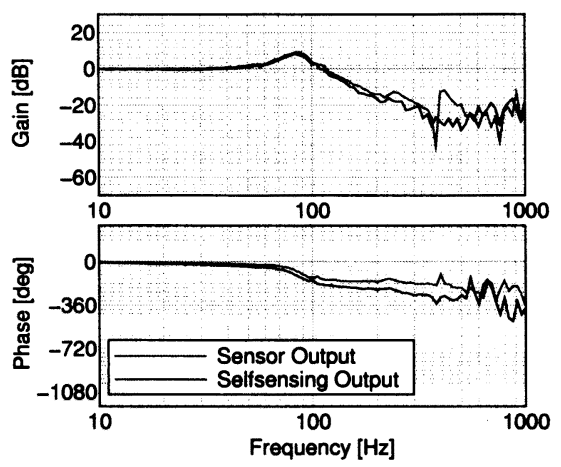

Fig. 14 Frequecy Response by Selfsensing Control ( $x$ axis, $\omega t=\frac{\pi}{4}$ )

アナライザで測定する. 変位センサ制御時, セルフセ ンシング制御時の測定結果を図 11 から図 14 に示す.

図 11 と 12 の測定結果から, 変位センサ制御時は减 衰が非常によく効いており，共振ピークが完全に抑え られていることが確認できる. また，セルフセンシン グ出力が変位センサ出力にほぼ追従しているというこ とが確認された.

図 13 と 14 のセルフセンシング制御時の測定結果 は，変位センサ制御に比べ，共振における減衰特性が 悪化していることが確認された. この原因は, 永久磁 石の影響によりセルフセンシング出力が微小に変動す るため, 変位センサ制御に比べ制御が不安定化しやす く, 制御特性が悪化したためではないかと考えられる. しかし，変位センサ制御ほどではないが，セルフセン シング制御による浮上回転が可能であると思われる.

4.3 浮上回転实検次に, 本モータの浮上回転 実験を行い, アンバランス応答の測定を行った. 測定 は, ロータの回転数を 100[rpm] ずつ上昇させていき, ロータの回転が安定したときに, 回転数に同期した振 


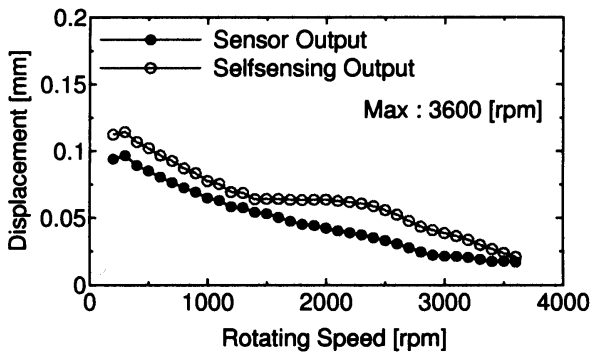

Fig. 15 Unbalance Response by Sensor Control

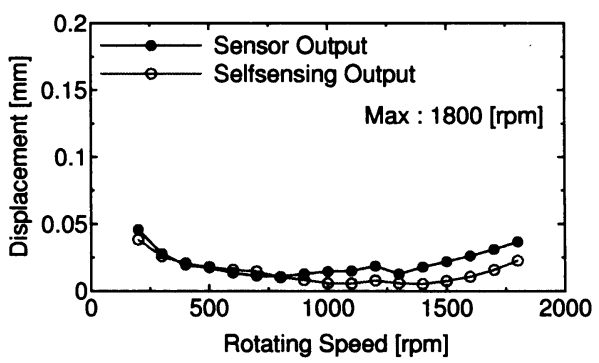

Fig. 16 Unbalance Response by Selfsensing Control

動振幅の最大值と最小値の差を測定した．変位センサ 制御時, セルフセンシング制御時のアンバランス応答 の測定結果をそれぞれ図 15,16 に示す. また, ロー 夕の触れ回りを確認するために, ロータの軌跡を測定 した．変位センサ制御時，セルフセンシング制御時の 測定結果をそれぞれ図 17,18 に示す. 測定結果から 変位センサ制御時は, 回転数の上昇に伴い, 振動振幅 が大きく减少していることが確認できる. そして, 回 転電圧の飽和する 3600[rpm] まで安定した浮上回転に 成功した.

セルフセンシング制御時には, 最高回転数は変位セ ンサ制御までは至らなかったが, 1800[rpm]までの浮 上回転に成功した. また, アンバランス応答は非常に 安定しているが, 実際の振動波形は回転成分以外を含 み, ある程度変動していることを図 18 のリサージュ波 形が示している. セルフセンシング制御はセンサ制御 と異なり，モータが回転することによって検出特性に 影響を与え, 不安定な変動を生じさせてしまったと考 えられる. しかし, このような変動があっても, 差動 トランス方式の変位推定によって, セルフベアリング モータの浮上回転が実現可能であることを確認した.

今後の課題としては, セルフセンシング制御の安定 性を改善し, 高速での浮上回転を実現する.また，口 バストな制御手法の導入が必要であると考えられる。
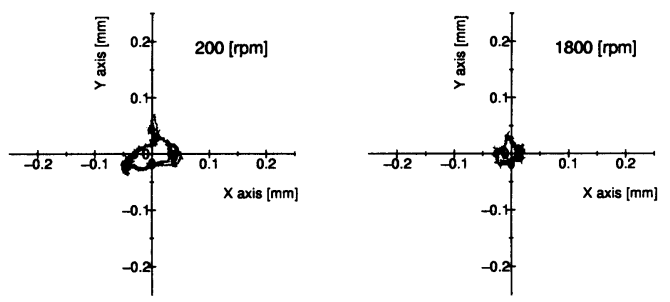

Fig. 17 Orbital Trajectory by Sensor Control
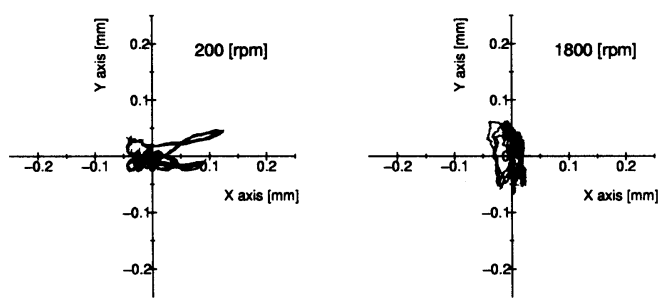

Fig. 18 Orbital Trajectory by Selfsensing Control

$$
\text { ま とめ }
$$

本論文では, 差動トランス方式によるセルフベアリ ングモータのセルフセンシング化を研究した. まず, 理論解析により差動トランス方式により変位推定が可 能であることを導いた. そして, 製作した実験装置を 用いて実験を行った結果, 別系統の検出巻線を用いた 場合に, セルフセンシング制御により, 最高 $1800[\mathrm{rpm}]$ までの浮上回転に成功した．このことから，本方式に よるセルフベアリングモータのセルフセンシング化が 可能であるということが示された.

\section{文献}

(1) Y. Okada, et. al., Analysis and Comparison of PM Synchronous Motor and Induction Motor Type Magnetic Bearing, IEEE Transactions on Industry Applications, Vol.31, No.5, September/October, 1995, pp.1047-1053

(2) D. Vischer and H. Bleuler, A New Approach to Sensorless and Voltage Controlled AMBs Based on Network Theory Concepts, Proc. of 2nd Int. Symp. on Magnetic Bearings, July 12-14, 1990, Tokyo, Japan, pp.301-306

(3) Y. Okada, K. Matsuda and B. Nagai, Sensorless Magnetic Levitation Control by Measuring the PWM Carrier Frequency Component, Proc. of 3rd Int. Symp. on Magnetic Bearings, 1992, Alexandria, VA.

(4) K. Matsuda et. al., Self-sensing Magnetic Bearing using the Principle of Differential Transformer, Proc of 5th Int. Symp. on Magnetic Bearings, August, 1996, Kanazawa, Japan, pp.107-112 